\title{
Mapping Reality and Virtuality: Paintings, Maps and Hydrographical Surveying about British and American Settlements of the Shanghai Bund, 1845-1860
}

\author{
FUNG Kam Wing ${ }^{\text {a, } *}$ \\ a The University of Hong Kong, fungkw@hku.hk \\ * Corresponding author
}

Keywords: Map of Shanghai Bund, British and American Settlements, Paintings and Hydrographical charts

\begin{abstract}
:
On $8^{\text {th }}$ November, 1843, Captain George Balfour (1809-1894) arrived in Shanghai to take up his position of the first British Consul in Shanghai. After he paid a visit to the Taotai 道台 of Shanghai Gong Wujiu 宮慕久 and had a discussion with the latter, both sides agreed and announced that Shanghai would be open to foreign trade since $17^{\text {th }}$ November, 1843. The boundary of the British Settlement was mentioned in Land Regulations of Shanghai, the promulgated agreement between Gong and Balfour in November 1845; the southern end of the British Settlement was Yang-Kin-Pan Creek (Yang King Pang or Yangjingbin 洋涇濱 Creek; now Yan'an Road East) and the northern end Lijia chang 李家廠 (now Beijing Road East) [Figure 1]. The eastern end was not mentioned in the Land Regulations and understood as Huangpu River 黃浦江. The western end was unsettled but in the following year, it was agreed that it would be Barrier Road (Jielu Road 界路, now Henan Road Central). A survey of the British Settlement at that time gave the area of 830 acres and land deeds were issued. In 1848, the American Settlement was established. Consul of the US and Britain as well as the authorities of the two settlements both hired professionals to map the two settlements or invited the surveyors of the two navies to draw navigational or channel survey maps from Huangpu River to Yangtze River. This paper will use paintings, maps and sources on hydrographical measurement to give a succinct account of the development of cartography and surveying of the British and the American Settlements between 1845 and 1860.
\end{abstract}

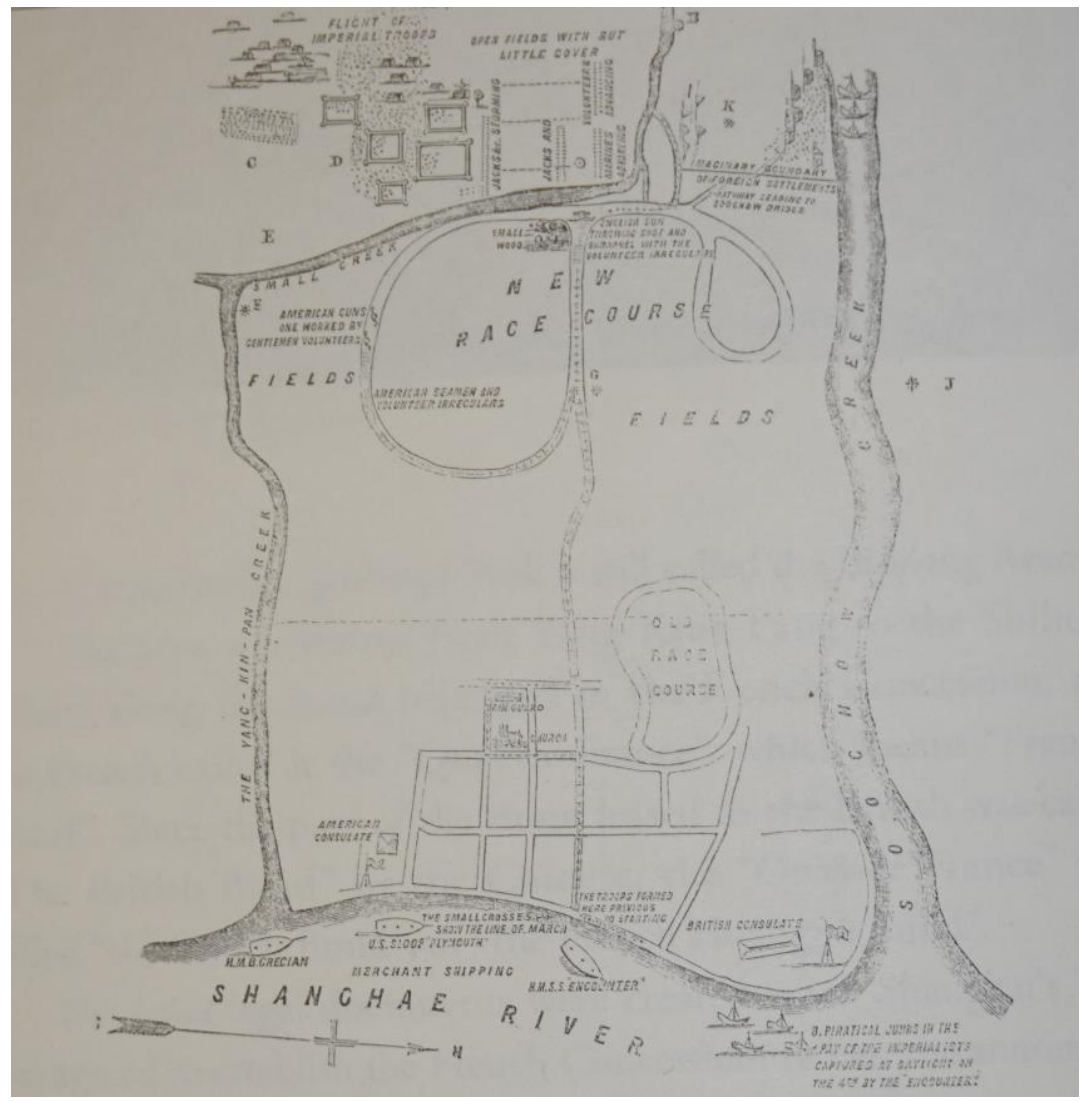

Figure 1: Map of British Settlement, Shanghai Bund, 1854 